\title{
Galectins and collectinis expression are increased in Haemonchus contortus-infected corriedale sheep
}

\author{
Aumento da expressão gênica de colectinas e galectinas em ovinos corriedale \\ infectados por Haemonchus contortus \\ Bárbara Maria Paraná da Silva Souza ${ }^{1 *}$; Sabrina Mota Lambert ${ }^{1}$; Sandra Mayumi Nishii ${ }^{1}$ Magda Vieira Benavides ${ }^{2}$; \\ Maria Elisabeth Aires Berne ${ }^{3}$; Claudio Roberto Madruga ${ }^{1}$; Maria Angela Ornelas de Almeida ${ }^{1}$ \\ ${ }^{1}$ Laboratório de Biologia Celular e Molecular, Universidade Federal da Bahia - UFBA, Salvador, BA, Brasil \\ ${ }^{2}$ Empresa Brasileira de Pesquisa Agropecuária - Embrapa LabEx, Beltsville, MD, USA \\ ${ }^{3}$ Universidade Federal de Pelotas - UFPEL, Pelotas, RS, Brasil
}

Received February 25, 2015

Accepted April 17, 2015

\begin{abstract}
Galectins and collectins are proteins classified in the lectin family that have the ability to recognize molecular patterns associated with pathogens. Studies on cattle have demonstrated high expression of these proteins during infection with gastrointestinal nematodes. The aim of this study was to investigate whether the level of Haemonchus contortus infection would alter the expression of galectins (Gal11 and Gal14) and collectins (SPA and CGN) in sheep. Twelve Corriedale sheep exposed to natural infection with nematodes were divided into two groups: group $1(\mathrm{G} 1, \mathrm{n}=7)$ and group 2 (G2, n = 5), with low and high parasite burdens, respectively, based on fecal egg counts and abomasal parasite counts. The fecal egg counts and abomasal parasite counts were significantly different $(\mathrm{p}<0.05)$ between the groups. Galectin and collectin gene expression was observed in all sheep abomasal samples. However, animals with lower infection levels showed lower expression of the genes Gal14, SPA and CGN $(\mathrm{p}<0.05)$. Expression of lectins was associated with the abomasal $H$. contortus burden, thus suggesting that these proteins may have a role in controlling of this infection.
\end{abstract}

Keywords: Innate immunity, lectins, helminths, small ruminants, PCR.

\section{Resumo}

Colectinas e galectinas são proteínas da família das lectinas que possuem a capacidade de reconhecer padróes moleculares associados aos patógenos. Estudos em bovinos têm demonstrado a alta expressão dessas proteínas durante a infecção por nematoides gastrintestinais. O objetivo deste estudo foi investigar se o nível de infecção de Haemonchus contortus altera a expressão de colectinas (SPA e CGN) e galectinas (Gal11 e Gal14) de ovinos. Doze ovinos da raça Corriedale expostos a infecção natural com nematoides foram separados em dois grupos: grupo 1 (G1, n=7) com menor grau de parasitismo; e grupo $2(\mathrm{G} 2, \mathrm{n}=5)$ com maior grau, a partir da contagem do número de parasitos recuperados do abomaso e OPG. A contagem de OPG e de parasitos recuperados do abomaso dos grupos G1 e G2 apresentaram diferença estatística $(\mathrm{p}<0,05)$. A expressão dos genes de colectinas e galectina foi observada em todas as amostras de abomaso dos ovinos, porém animais com menor grau de infecção apresentaram menor expressão dos genes de Gal14, SPA e CGN $(\mathrm{p}<0,05)$. A expressáo de lectinas foi associada ao número de $H$. contortus encontrados no abomaso de ovinos, indicando um possível papel dessas proteínas no controle da infecção.

Palavras-chave: Imunidade inata, lectinas, helmintos, pequenos ruminantes, PCR.

\section{Introduction}

Haemonchosis is responsible for low performance and can cause severe disruption to sheep production chain in many tropical and subtropical regions, where it is endemic. Selection of sheep that are

*Corresponding author: Bárbara Maria Paraná da Silva Souza. Laboratório de Biologia Celular e Molecular, Escola de Medicina Veterinária e Zootecnia, Universidade Federal da Bahia - UFBA, Av. Adhemar de Barros, 500, CEP 40170-110, Salvador, BA, Brasil. e-mail: bparana@ufba.br genetically resistant to gastrointestinal nematodes is an alternative control method (KASSAI \& SRETER, 1992), which is based on the animal's ability to acquire immunity and limit the establishment of the parasite, thereby reducing productivity losses.

Host immunity against helminth infections is dependent on innate and acquired immune responses (STEAR \& WAKELIN, 1998) and the interaction of these responses confers protection by inducing 
eosinophilic inflammation, mastocytosis and activation of Th2 responses, with increased expression of interleukin (IL) -4, IL-5 and IL-13 in target tissues and production of $\operatorname{IgE}$ and $\operatorname{IgA}$ (MACKINNON et al., 2009, 2010). In contrast, animals susceptible to infection develop Th1 responses, with secretion of cytokines such as IL-2, interferon-gamma (IFNG) and tumor necrosis factor (GILL et al., 2000).

In addition to Th1 or Th2-triggered responses to helminth antigens, other components may influence the host's ability to control parasitism. Recognition proteins such as lectins are involved in the immune response against nematodes (MEEUSEN et al., 2005). In particular, members of the galectin and the C-type lectin family have been identified in the abomasum of cattle and sheep infected with Ostertagia ostertagi and Cooperia oncophora (DUNPHY et al., 2000; LI \& GASBARRE, 2009; LI et al., 2010; ROBINSON et al., 2011). Collectins belong to a mammalian superfamily of the lectin C-type protein subgroup with the ability to recognize pathogen-associated molecular patterns (PAMPs) found on the surface of microorganisms (KILPATRICK, 2002). These proteins inhibit the infectious process through neutralization, agglutination and complement activation, they also act as immunomodulators of allergic and inflammatory responses and apoptosis (DEC \& WERNICKI, 2006; HÅKANSSON \& REID, 2000). Galectins are defined through recognition of $\beta$-galactoside, by means of a calcium-independent carbohydrate recognition domain (BARONDES et al., 1994), through the immune response involved in regulating cell differentiation, modulation of cell adhesion and activation, and chemotaxis (LIU, 2005).

These mechanisms are not fully understood in nematode-ruminant interactions, but some hypotheses have been suggested. In primary infection of cattle with $O$. ostertagi, increased expression of collectin, conglutinin and CL-46, in the abomasal mucosa has been observed, along with increased protein regulation of the full complement C3, complement factor B and complement factor I. This suggests that there is activation of the alternative complement pathway and early reactivation in secondary infections (LI et al., 2010). Another response mechanism observed in $H$. contortus-infected sheep is characterized by abundant secretion of galectin-11 in the abomasum, increased mucus production (DUNPHY et al., 2000) and alteration of mucus viscosity, thus providing an unfavorable environment for parasite survival (ROBINSON et al., 2011).

The nature of nematode contact with components of the innate immune system of ruminants is decisive in determining the resistance or susceptibility of the host. The present study investigated whether the gene expression of galectins (Gal11 and Gal14) and collectins (SPA and CGN) in sheep differed between groups with different levels of $H$. contortus infection, thereby contributing towards better understanding of the innate immune response against gastrointestinal helminths, based on the premise that lectins are pattern recognition molecules of the cell surface of parasites.

\section{Material and Methods}

\section{Animals}

Twelve 18-month-old Corriedale sheep (both males and females) were used in the experiment. The animals were exposed to natural infection with helminths at the Embrapa Pecuária Sul research farm, in Bagé $\left(31^{\circ} \mathrm{S} 54^{\circ} \mathrm{W}\right)$, Rio Grande do Sul, Brazil. After 12 months of monitoring, the animals were slaughtered to recover parasites and obtain abomasal mucosa samples. All procedures followed were in accordance with the Brazilian legislation, as per Resolution no. 1000/2012 of the Federal Council of Veterinary Medicine and were approved by our institution's ethics committee for animal use (March 29, 2011). The animals were divided into two groups: low $(\mathrm{G} 1, \mathrm{n}=7)$ and high $(\mathrm{G} 2, \mathrm{n}=5)$ levels of $H$. contortus parasitism. The division was based on fecal egg counts (FEC) and abomasal parasite counts, after performing ascending hierarchical multivariate cluster analysis, using Euclidean distance as the algorithm for the complete-link method (JOHNSON \& WICHERN, 1998), in order to obtain an estimate of the animals' profile in terms of their degree of parasitism (V-Statistics software 6.0).

Fecal samples were collected directly from the rectum in order to count the number of nematode eggs per gram of feces (FEC) (UENO \& GONÇALVES, 1998). Blood samples were taken by means of jugular venipuncture and collected in tubes containing $10 \%$ ethylenediaminetetraacetic acid (EDTA) for hematocrit determination and white blood cell counts (JAIN, 1993). The abomasal samples were stored in stabilizing solution (RNALater ${ }^{\circledR}$, Applied Biosystems, USA) at $-70{ }^{\circ} \mathrm{C}$ for gene expression quantification and analyses.

\section{$R N A$ extraction and $c D N A$ synthesis}

Total RNA was obtained from approximately 50 to $100 \mathrm{mg}$ of tissue that was homogenized in liquid nitrogen and homogenized in $1 \mathrm{~mL}$ of TRIzol reagent (Invitrogen, USA), following the manufacturer's recommendations. The RNA quality was confirmed by means of electrophoresis on $1.5 \%$ agarose gel, stained with Sybr Gold (Invitrogen, USA) and the RNA concentration was estimated using the Quant-i $T^{\mathrm{TM}}$ RNA assay kit in a Qubit fluorometer (Invitrogen, USA). The RNA samples were treated with DNase and incubated for 15 min to remove any genomic DNA residue. cDNA was obtained by means of the reverse transcription reaction (RT) using the SuperScript ${ }^{\circledR}$ III reverse transcriptase kit (Invitrogen, USA), Oligo (dT) 12-18 oligonucleotides and RNase inhibitors, following the conditions described by the manufacturer

\section{Real-time PCR}

Seven different oligonucleotide primers were used, along with a Glyceraldehyde 3-phosphate dehydrogenase (GAPDH) endogenous control and six target genes: two collectins (CGN and SPA), two galectins (Gal14 and Gal11) and two cytokines (interleukin-4 (IL-4) and IFNG) (Box 1). Primers for CGN and SPA were designed based on data from GenBank, and the remainder were based on literature: galectins 11 and 14 (ROBINSON et al., 2011), IL-4 (HEIN et al., 2010) and IFNG (LACROUX et al., 2006). Due to the absence of data in the literature regarding collectin sequences in sheep, oligonucleotides were designed based on bovine collectin mRNA sequences in GenBank (http:// www.ncbi.nlm.nih.gov/genbank/). The amplified fragments were subjected to sequencing and the results were used to design sheep collectin gene expression primers by using the Primer Express software, version 3.0 (Applied Biosystems, USA). The specificity 
Box 1. Sequences of primers used in the qPCR reaction and their GenBank accession number.

\begin{tabular}{lll}
\hline Gene & Oligonucleotides & GenBank \\
\hline GAPDH & & \multirow{2}{*}{ AF272837 } \\
\hline GAPDH-R & 5'-ATGGTCTACATGTTCCAGTATGATTCC-3 & KF130969 \\
\hline GAPDH-F & 5'- TGACGAGCTTCCCGTTCTCT -3' & \\
\hline Conglutinin & & \\
\hline CGN-R & 5'- GAGAATGAGGCCGTGACACA -3' & KF130970 \\
\hline CGN- F & 5'- ACCTCCCCTCCGTGGAGAT -3' & \\
\hline Surfactant protein A (SP-A) & & \\
\hline SP-A F & 5'-CTGCCTGCTGATGAACACATT-3' \\
\hline SP-A R & 5'-GCATGTCAAGGTGCTTGGTGTA-3'
\end{tabular}

and identifications of oligonucleotides were double-checked using the Basic Local Alignment Search Tool (BLAST; http://blast.ncbi. nlm.nih.gov/Blast.cgi).

The GoTaq qPCR kit (Promega, USA) was used to amplify the sequences, in accordance with the manufacturer's instructions. Each sample was tested as duplicates, with 100 ng of cDNA per reaction and 10 pmol of each specific primer, in a final volume of $20 \mu \mathrm{l}$. The PCR reaction was performed in the 7500 Real-Time PCR apparatus (Applied Biosystems, USA). Samples with a positive reaction were detected by means of fluorescence emission at each amplification cycle and were subsequently analyzed by using the Sequence Detection software, version 2.0.3 (Applied Biosystems). For gene expression analysis, the average values of duplicate readings were used. Results, expressed as CT values, indicated the number of PCR cycles necessary for signal amplification to reach detection threshold levels (SDS v.1.3, Applied Biosystems). Gene expression quantification was performed using the $\triangle \mathrm{CT}$ method $(\triangle \mathrm{CT}=$ target $\mathrm{CT}$ gene minus $\mathrm{CT}$ endogenous gene control), with GAPDH as the endogenous control, and was expressed as relative values normalized against an arbitrary factor of 20 (ROBINSON et al., 2011).

\section{Statistical analysis}

Differences between groups were compared by means of the Mann-Whitney test and correlations between variables using the Spearman correlation test, a P-value $<0.05$ was considered significant (SPSS v. 17, IBM, USA).

\section{Results}

Significant differences between the two groups were observed in relation to FEC counts and parasite counts. Mucosal eosinophil counts, hemoglobin, hematocrit and plasma protein values did not differ between the groups (Table 1 ). H. contortus was the only species found in the abomasum of these animals.

Gene expression of galectins and collectins was observed in all sheep abomasal samples. However, animals with lower infection had lower gene expression levels of Gal14, SPA and CGN than shown by those in the high infection group $(\mathrm{p}<0.05)$ (Figure 1$)$.
Table 1. Mean \pm standard deviation values of parasitological and hematological traits of Corriedale sheep with lower (G1) and higher (G2) Haemonchus contortus parasitism level.

\begin{tabular}{|c|c|c|c|}
\hline \multirow{2}{*}{ Traits } & \multicolumn{2}{|c|}{ Groups } & \multirow{2}{*}{$\mathbf{p}^{\dagger}$} \\
\hline & G1 & G2 & \\
\hline Faecal egg count (FEC) & $0 \pm 0$ & $680.0 \pm 831.9$ & 0.05 \\
\hline $\begin{array}{l}\text { Abomasal } H \text {. contortus } \\
\text { burden (L4 and L5) }\end{array}$ & $10.6 \pm 8.3$ & $59.2 \pm 27.7$ & 0.01 \\
\hline $\begin{array}{l}\text { Mucosal eosinophil } \\
\text { count }\left(\mathrm{mm}^{2}\right)\end{array}$ & $24.9 \pm 5.4$ & $25.1 \pm 3.9$ & 0.91 \\
\hline $\begin{array}{l}\text { Total leukocyte count } \\
\qquad\left(\times 10^{3} / \mu \mathrm{L}\right)\end{array}$ & $5857.1 \pm 1444.4$ & $4920.0 \pm 1435.1$ & 0.29 \\
\hline Hematocrit (\%) & $31.4 \pm 1.3$ & $30.4 \pm 2.3$ & 0.40 \\
\hline $\begin{array}{l}\text { Total serum protein } \\
(\mathrm{g} / \mathrm{dL})\end{array}$ & $7.1 \pm 0.3$ & $6.7 \pm 0.6$ & 0.28 \\
\hline
\end{tabular}

$H$. contortus infection levels did not affect the gene expression levels of Gal11, IL-4 or IFNG.

Gal14 gene expression levels and abomasal parasite burden were negatively correlated, while there were strong positive correlations among IFNG, Gal14, SPA and IL-4 (Table 2). Within-group testing found strong positive correlations between G1/G1 SPA and IL-4 ( $\mathrm{r}=0.893 ; \mathrm{p}=0.012)$; G1/G1 IL-4 and IFNG ( $\mathrm{r}=0.929 ; \mathrm{p}=0.007)$; G2/G2 abomasal parasite burden and Gal14 ( $\mathrm{r}=1.00 ; \mathrm{p}=0.017)$; and G1/G1 eosinophil count and CGN $(r=0.982 ; \mathrm{p}=0.0004)$.

\section{Discussion}

All the animals, exposed to natural infection, were similar in age, breed, health program and supplementary feeding system. They were kept in the same paddock and were subjected to repeated gastrointestinal nematode challenge and infections. The overall low FEC and abomasal parasite burden was a consequence of anthelmintic treatment performed two weeks before slaughter, because of extreme FEC counts. As a consequence, the number of parasites in both 
CGN

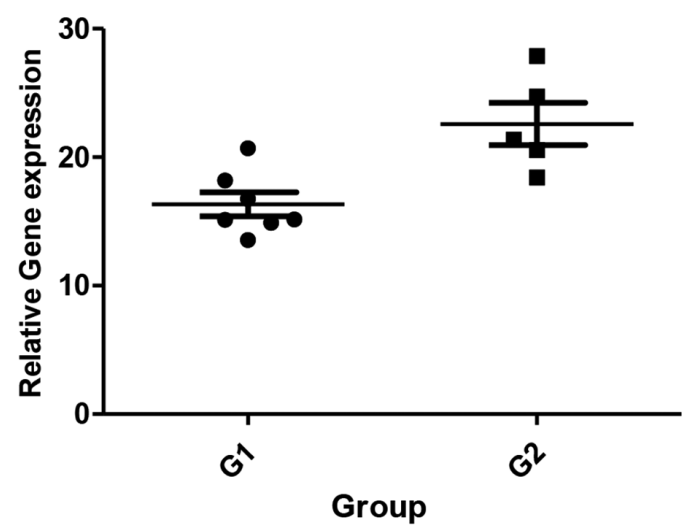

Gal14
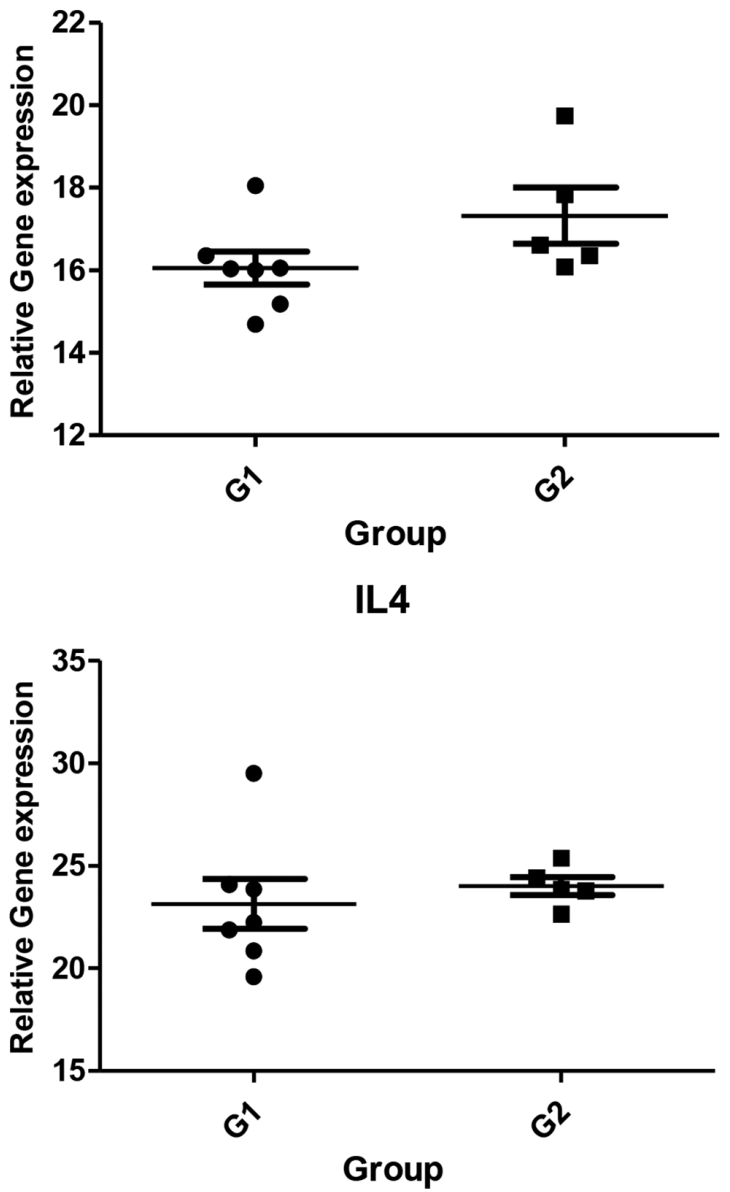

SPA

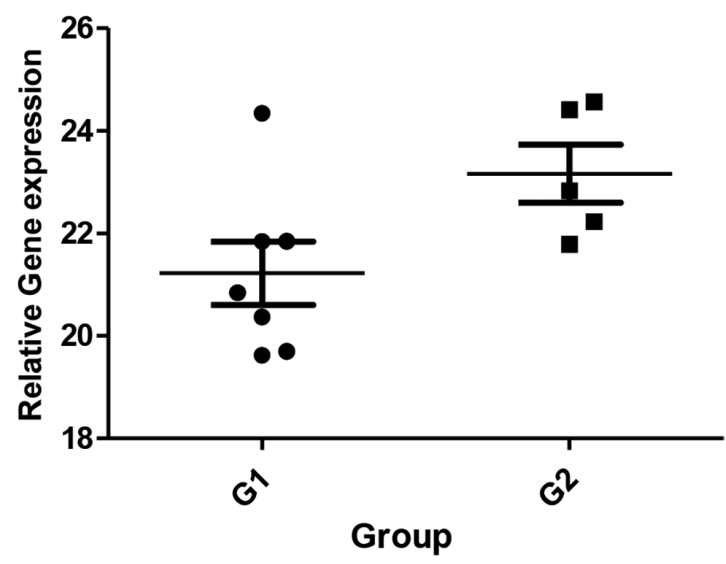

Gal11

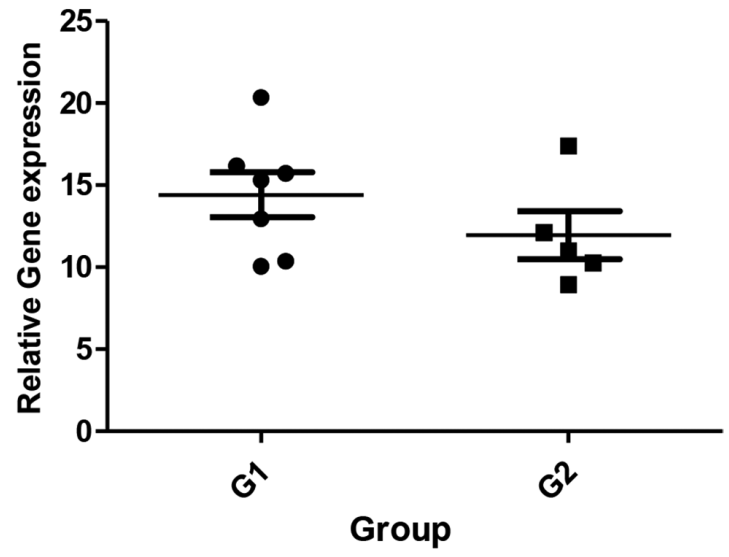

IFNG

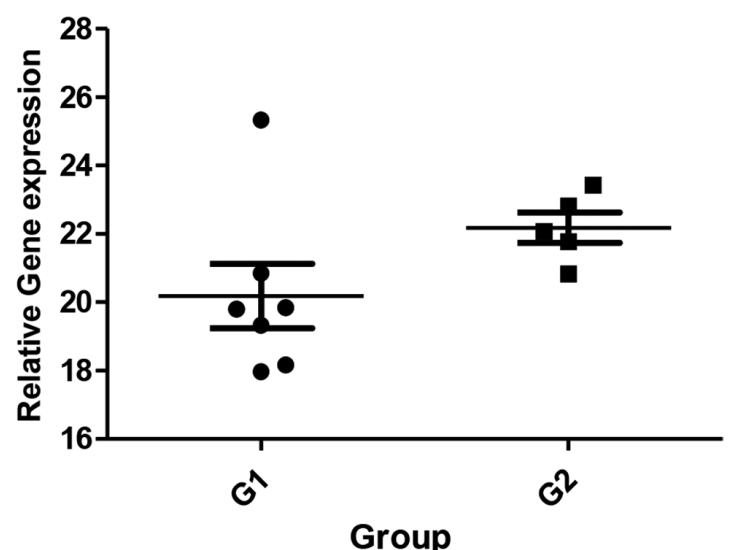

Figure 1. Conglutinin (CGN), surfactant protein A (SPA), galectins-14 (Gal14) and 11 (Gal11), interleukin 4 (IL4) and interferon gamma (IFNG) relative gene expression in low (G1) and high (G2) Haemonchus contortus infected Corriedale sheep.

groups decreased, and this intervention might explain the absence of other nematode species. Nonetheless, significant differences between parasitism levels were detected between the two groups.

There were no differences in hematological and biochemical parameters between the groups, which may have been due to the improvement of physiological conditions after anthelmintic treatment. A steady leukocyte count response in cases of gastrointestinal nematode infection, especially regarding abomasal eosinophil counts, was observed by Amarante et al., (2005) and Terefe et al., (2007) when studying sheep that were resistant and susceptible to $H$. contortus infection. This was seen because mobilization of effector cells is important in the early days of infection (TEREFE et al., 2009). This argument may also be an explanation for our findings, since the sheep had chronic infection. 
The sheep with high $H$. contortus infection levels showed higher conglutinin (CGN), surfactant protein A (SPA) and galectin 14 (Gal14) gene expression levels than shown by the sheep with low $H$. contortus infection levels (Table 2). Similar behavior was observed in studies on cattle experimentally infected with $O$. ostertagi and C. oncophora (LI \& GASBARRE, 2009; LI et al., 2010), in which collectin-46, conglutinin and galectin-11 gene expression levels increased in animals after repeated infection or during the course of infection, revealing that tissue response is a dynamic process and the peak of the expression of these and other genes was detected between the 14-28th day post infection. In our study, it was possible to measure the variation in expression in sheep kept under natural pasture conditions but in low magnitude and the the lack of correlation of other genes and tissue eosinophils may be related to the moment of the host response and infection phase.

Conglutinin and SPA appear to have an indirect effect on the immune response. SPA is capable of limiting inflammation and tissue damage during bacterial or fungal infection (GIANNONI et al., 2006; MADAN et al., 2010), as demonstrated in Mycoplasma pneumoniae-infected mice, in which SPA inhibited the binding of eosinophils to bacteria and therefore reduced the release of eosinophil peroxidase protein, which was implicated in the killing of pathogens (LEDFORD et al., 2012). In Aspergillus fumigatus infection, SPA inhibited the binding of $\operatorname{IgE}$ to basophils and prevented the release of histamine (MADAN et al., 1997). In contrast, $A$. fumigatus infected SPA-deficient knockout mice (- / -), showed protein pulmonary eosinophilia and increased tissue damage (MADAN et al., 2005), after SPA had been administered. These events emphasize that SPA can perform both functions as a pro-inflammatory or anti-inflammatory agent and, perhaps for this reason, there were high positive correlations between SPA and IL-4 and between SPA and IFNG in H. contortus-infected sheep.

The conglutinin studied here had, up until now, been regarded a bovine-specific protein. The present study provides the first description of an association between $H$. contortus infection levels and conglutinin and SPA gene expression levels, in sheep. The action of conglutinin is not restricted to antimicrobial activity: it can also serve as an anti-inflammatory agent for maintaining symbiosis and

Table 2. Correlation between cytokine gene expression, collectins and abomasal Haemonchus contortus counts.

\begin{tabular}{lcc}
\hline \multicolumn{1}{r}{ Parameters } & r & p ${ }^{\dagger}$ \\
\hline H. contortus burden & & \\
Gal14 & -0.608 & 0.036 \\
IL4 & & \\
SPA & 0.818 & 0.001 \\
IFNG & 0.748 & 0.005 \\
IFNG & & \\
SPA & 0.790 & 0.002 \\
Gal14 & 0.755 & 0.005 \\
Eosinophil count & -0.691 & 0.013 \\
SPA & & \\
Gal14 & & \\
\hline
\end{tabular}

$\dagger$ A p-value $<0.05$ was considered significant. preventing abomasum inflammation (HANSEN et al., 2002, 2003). Interestingly, we observed a strong correlation between CGN and eosinophil counts at low $H$. contortus infection levels, thus suggesting that, like SPA, these collectins may act by inhibiting the release of inflammatory substances, even though it is not known which collectins are regulated during abomasal infection. However, because of the high similarity of the CL-43, CL-46 and conglutinin sequences in cattle, the primer CGN annealed a conserved collectin sequence.

Unlike collectins, it has been suggested that Gal14 has a direct effect on nematodes, since high correlation was found between these protein levels and the abomasal parasite burden, in both between and within-group analyses. This galectin is considered to be an eosinophil-specific protein (DUNPHY et al., 2002): it is abundantly present in the mucus of the gastrointestinal tract after parasite challenge (ROBINSON et al., 2011) and has a strong ability to promote adhesion and alter mucus properties during infection (YOUNG et al., 2009). Interestingly, no strong correlation between eosinophil counts and Gal14 gene expression levels was observed, thus coinciding with the results found by Robinson et al., (2011) in sheep after experimental infection with H. contortus. High expression of Gal14 may be a consequence of the exposure period, since Gal14 becomes more sensitive to eosinophil degranulation after repeated infections (KEMP et al., 2009).

The gene expression of IL-4 and IFNG showed no difference between the groups. The high correlation observed between IL-4 and IFNG confirms that both of these cytokines can be elicited in the same environment during gastrointestinal nematode infection, as also described by Meeusen et al. (2005) and by Pernthaner et al. (2006). Understanding the factors that lead to polarization and differentiation of Th1 and Th2 responses in gastrointestinal nematode infections in ruminants is complex (LI et al., 2010; ROBINSON et al., 2011). Polarization is not as important as the speed at which these responses become established, such that animals that are resistant to nematodes are able to adjust more quickly to the Th2 response (TEREFE et al., 2007).

In conclusion, we have demonstrated that $H$. contortus-infected sheep showed induction of gene expression for conglutinin, surfactant protein A and galectin-14, and that the group with the highest degree of infection also showed the highest gene expression for these proteins. From these results together, it was possible to determine that the abomasal $H$. contortus count in sheep is associated with the expression of collectins and Gal14, may participate in the host defense against the gastrointestinal nematode infection. Lectins can act as pro- or anti-inflammatory markers according to different interactions at different moments of the infection. However, these results constitute merely an initial step towards identifying the role of galectins and collectins in sheep gastrointestinal nematode infections.

\section{Acknowledgements}

We wish to thank the Coordenação de Aperfeiçoamento de Pessoal de Nível Superior (CAPES, Brazil) for providing a PhD scholarship and the Centro Nacional de Desenvolvimento Científico e Tecnológico $(\mathrm{CNPq})$ for funding the experiment. 


\section{References}

Amarante AFT, Bricarello PA, Huntley JF, Mazzolin LP, Gomes JC. Relationship of abomasal histology and parasite-specific immunoglobulin A with the resistance to Haemonchus contortus infection in three breeds of sheep. Vet Parasitol 2005; 128(1-2): 99-107. http://dx.doi.org/10.1016/j. vetpar.2004.11.021. PMid:15725538.

Barondes SH, Cooper DNW, Gitt MA, Leffler H. Galectins. Structure and function of a large family of animal lectins. J Biol Chem 1994; 269(33): 20807-20810. PMid:8063692.

Dec M, Wernicki A. Conglutinin, CL-43 and CL-46--three bovine collectins. Pol J Vet Sci 2006; 9(4): 265-275. PMid:17203746.

Dunphy JL, Balic A, Barcham GJ, Horvath AJ, Nash AD, Meeusen EN. Isolation and characterization of a novel inducible mammalian galectin. J Biol Chem 2000; 275(41): 32106-32113. http://dx.doi.org/10.1074/ jbc.M003739200. PMid:10851241.

Dunphy JL, Barcham GJ, Bischof RJ, Young AR, Nash A, Meeusen $\mathrm{EN}$. Isolation and characterization of a novel eosinophil-specific galectin released into the lungs in response to allergen challenge. J Biol Chem 2002; 277(17): 14916-14924. http://dx.doi.org/10.1074/jbc.M200214200. PMid:11839756.

Giannoni E, Sawa T, Allen L, Wiener-Kronish J, Hawgood S. Surfactant proteins A and D enhance pulmonary clearance of Pseudomonas aeruginosa. Am J Respir Cell Mol Biol 2006; 34(6): 704-710. http://dx.doi.org/10.1165/ rcmb.2005-0461OC. PMid:16456184.

Gill HS, Altmann K, Cross ML, Husband AJ. Induction of T helper 1 - and T helper 2-type immune responses during Haemonchus contortus infection in sheep. Immunology 2000; 99(3): 458-463. http://dx.doi. org/10.1046/j.1365-2567.2000.00974.x. PMid:10712677.

Håkansson K, Reid KB. Collectin structure: a review. Protein Sci 2000; 9(9): 1607-1617. http://dx.doi.org/10.1110/ps.9.9.1607. PMid:11045608.

Hansen S, Holm D, Moeller V, Vitved L, Bendixen C, Reid KBM, et al. CL-46, a novel collectin highly expressed in bovine thymus and liver. J Immunol 2002; 169(10): 5726-5734. http://dx.doi.org/10.4049/ jimmunol.169.10.5726. PMid:12421952.

Hansen S, Holm D, Moeller V, Vitved L, Bendixen C, Skjoedt K, et al. Genomic and molecular characterization of CL-43 and its proximal promoter. Biochim Biophys Acta 2003; 1625(1): 1-10. http://dx.doi. org/10.1016/S0167-4781(02)00531-6. PMid:12527419.

Hein WR, Pernthaner A, Piedrafita D, Meeusen EN. Immune mechanisms of resistance to gastrointestinal nematode infections in sheep. Parasite Immunol 2010; 32(8): 541-548. PMid:20626809.

Jain NC. Essentials of veterinary hematology. Philadelphia: Lea e Febiger; 1993.

Johnson RA, Wichern DW. Applied Multivariate Statistical Analysis. 4th ed. Upper Saddle River: Prentice Hall; 1998.

Kassai T, Sreter T. Genetic aspects of the host resistance to helminthic infections. Res Rev Parasitol 1992; 52(3-4): 67-75.

Kemp JM, Robinson NA, Meeusen ENT, Piedrafita DM. The relationship between the rapid rejection of Haemonchus contortus larvae with cells and mediators in abomasal tissues in immune sheep. Int J Parasitol 2009; 39(14): 1589-1594. http://dx.doi.org/10.1016/j.ijpara.2009.05.015. PMid:19540240.
Kilpatrick DC. Animal lectins: a historical introduction and overview. Biochim Biophys Acta 2002; 1572(2-3): 187-197. http://dx.doi.org/10.1016/ S0304-4165(02)00308-2. PMid:12223269.

Lacroux C, Nguyen TH, Andreoletti O, Prevot F, Grisez C, Bergeaud JP, et al. Haemonchus contortus (Nematoda: Trichostrongylidae) infection in lambs elicits an unequivocal Th2 immune response. Vet Res 2006; 37(4): 607-622. http://dx.doi.org/10.1051/vetres:2006022. PMid:16701066.

Ledford JG, Mukherjee S, Kislan MM, Nugent JL, Hollingsworth JW, Wright JR. Surfactant protein-A suppresses eosinophil-mediated killing of Mycoplasma pneumoniae in allergic lungs. PLoS One 2012; 7(2): e32436. http://dx.doi.org/10.1371/journal.pone.0032436. PMid:22384248.

Li RW, Gasbarre LC. A temporal shift in regulatory networks and pathways in the bovine small intestine during Cooperia oncophora infection. Int J Parasitol 2009; 39(7): 813-824. http://dx.doi.org/10.1016/j. ijpara.2008.11.007. PMid:19116156.

Li RW, Hou Y, Li C, Gasbarre LC. Localized complement activation in the development of protective immunity against Ostertagia ostertagi infections in cattle. Vet Parasitol 2010; 174(3-4): 247-256. http://dx.doi. org/10.1016/j.vetpar.2010.08.037. PMid:20884121.

Liu FT. Regulatory roles of galectins in the immune response. Int Arch Allergy Immunol 2005; 136(4):385-400. http://dx.doi.org/10.1159/000084545. PMid:15775687.

MacKinnon KM, Burton JL, Zajac AM, Notter DR. Microarray analysis reveals difference in gene expression profiles of hair and wool sheep infected with Haemonchus contortus. Vet Immunol Immunopathol 2009 130(3-4): 210-220. http://dx.doi.org/10.1016/j.vetimm.2009.02.013. PMid:19346008.

MacKinnon KM, Zajac AM, Kooyman FNJ, Notter DR. Differences in immune parameters are associated with resistance to Haemonchus contortus in Caribbean hair sheep. Parasite Immunol 2010; 32(7): 484-493. http:// dx.doi.org/10.1111/j.1365-3024.2010.01211.x. PMid:20591119.

Madan T, Kishore U, Shah A, Eggleton P, Strong P, Wang JY, et al. Lung surfactant proteins $\mathrm{A}$ and $\mathrm{D}$ can inhibit specific IgE binding to the allergens of Aspergillus fumigatus and block allergen-induced histamine release from human basophils. Clin Exp Immunol 1997; 110(2): 241-249. http://dx.doi.org/10.1111/j.1365-2249.1997.tb08323.x. PMid:9367408.

Madan T, Reid KB, Singh M, Sarma PU, Kishore U. Susceptibility of mice genetically deficient in the surfactant protein (SP)-A or SP-D gene to pulmonary hypersensitivity induced by antigens and allergens of Aspergillus fumigatus. J Immunol 2005; 174(11): 6943-6954. http:// dx.doi.org/10.4049/jimmunol.174.11.6943. PMid:15905537.

Madan T, Reid KBM, Clark H, Singh M, Nayak A, Sarma PU, et al. Susceptibility of mice genetically deficient in SP-A or SP-D gene to invasive pulmonary aspergillosis. Mol Immunol 2010; 47(10): 1923-1930. http://dx.doi.org/10.1016/j.molimm.2010.02.027. PMid:20413160.

Meeusen ENT, Balic A, Bowles V. Cells, cytokines and other molecules associated with rejection of gastrointestinal nematode parasites. Vet Immunol Immunopathol 2005; 108(1-2): 121-125. http://dx.doi.org/10.1016/j. vetimm.2005.07.002. PMid:16099054

Pernthaner A, Cole SA, Morrison L, Green R, Shaw RJ, Hein WR. Cytokine and antibody subclass responses in the intestinal lymph of sheep during repeated experimental infections with the nematode parasite Trichostrongylus colubriformis. Vet Immunol Immunopathol 2006 114(1-2): 135-148. http://dx.doi.org/10.1016/j.vetimm.2006.08.004 PMid:16956667. 
Robinson N, Pleasance J, Piedrafita D, Meeusen EN. The kinetics of local cytokine and galectin expression after challenge infection with the gastrointestinal nematode, Haemonchus contortus. Int J Parasitol 2011; 41(5): 487-493. http://dx.doi.org/10.1016/j.ijpara.2010.11.006. PMid:21172352.

Stear MJ, Wakelin D. Genetic resistance to parasitic infection. Rev Sci Tech 1998; 17(1): 143-153. PMid:9638807.

Terefe G, Lacroux C, Andreoletti O, Grisez C, Prévot F, Bergeaud JP, et al. Immune response to Haemonchus contortus infection in susceptible (INRA 401) and resistant (Barbados Black Belly) breeds of lambs. Parasite Immunol 2007; 29(8): 415-424. http://dx.doi.org/10.1111/j.13653024.2007.00958.x. PMid:17650183.
Terefe G, Lacroux C, Prévot F, Grisez C, Bergeaud JP, Bleuart C, et al. Eosinophils in Haemonchus contortus-infected resistant and susceptible breeds of sheep: abomasal tissue recruitment and in vitro functional state. Vet Parasitol 2009; 165(1-2): 161-164. http://dx.doi.org/10.1016/j. vetpar.2009.06.041. PMid:19733438.

Ueno H, Gonçalves PC. Manual para diagnóstico das helmintoses de ruminantes. 4th ed. Tokyo: Japan International Cooperation Agency; 1998.

Young AR, Barcham GJ, Kemp JM, Dunphy JL, Nash A, Meeusen EN. Functional characterization of an eosinophil-specific galectin, ovine galectin-14. Glycoconj J2009; 26(4): 423-432. http://dx.doi.org/10.1007/ s10719-008-9190-0. PMid:18810635. 